\title{
The correlation between histologic placentitis and amnionitis and the amniotic fluid's inflammatory cytokines in case of spontaneous pre-term labor with intact membrane
}

\author{
Agus Abadi
}

\begin{abstract}
Abstrak
Persalinan preterm diperkirakan sebagai akibat penjalaran infeksi genitalia bagian bawah ke atas, terutama ke jaringan desidua dan korioamniotik. Respons tubuh terhadap jejas semacam ini antara lain dengan diekspresikannya protein-protein yang berperan dalam proses inflamasi. Ekspresi IL-1 $\beta, I L-6, I L-8$ dan TNF- $\alpha$ akan meningkat pada keadaan infeksi. Sitokin-sitokin ini mungkin mempunyai peran yang mendasar terhadap patofisiologi terjadinya persalinan preterm spontan dengan ketuban yang masih intak. Penelitian observasional ialah untuk membuktikan hubungan antara 1 histologik amnionitis dan plasentitis dengan kejadian persalinan preterm, 2) ekspresi $I L-1 \beta, I L-6, I L-8$ dan TNF- $\alpha$ dalam air ketuban dengan kejadian persalinan preterm, 3) derajat histologik amnionitis dan plasentitis dengan kadar IL-1 $\beta, I L-6, I L-8$ dan TNF- $\alpha$ dalam air ketuban pada kasus persalinan preterm spontan dengan ketuban yang masih intak. Terhadap kasus-kasus persalinan preterm spontan dengan ketuban yang masih intak dilakukan amniosentesis transabdominal pada saat masuk kamar bersalin dan selanjutnya dirawat sesuai dengan protap untuk kasus dengan persalinan preterm dengan ketuban yang masih intak. Semua kasus yang mengikuti penelitian diobservasi sampai dengan terjadinya persalinan aterm maupun preterm. Spesimen selaput ketuban dan plasenta untuk pemeriksaan histologik diambil pasca persalinan, kemudian dilakukan pemeriksaan adanya tanda-tanda suatu inflamasi akut berdasarkan kriteria Salafia. Kadar IL-I $\beta, I L-6, I L-8$ dan TNF- $\alpha$ dalam air ketuban dianalisis secara kuantitatif dengan metoda Elisa. Pada penelitian ini ditemukan bahwa derajat histologik amnionitis dan plasentitis, kadar $I L-I \beta, I L-6, I L-8$ dan TNF- $\alpha$ dalam air ketuban pada persalinan preterm lebih tinggi dibanding pada persalinan aterm $(p<0,05)$ dan ditemukan juga adanya korelasi yang positip antara derajat inflamasi dengan kadar IL-I $\beta$, IL6, IL-8 dan TNF- $\alpha$ dalam air ketuban (Spearmann Rank "Correlation test; $p<0,05$ ). Disimpulkan bahwa makin tinggi derajat inflamasi pada amnion dan plasenta, makin tinggi kadar IL-1 $\beta, I L-6, I L-8$ dan TNF- $\alpha$ dalam air ketuban akan makin tinggi pula risiko terjadinya persalinan preterm. Korelasi yang ditemukan pada penelitian ini menunjukkan penjalaran proses inflamasi dari selaput ketuban dan plasenta ke dalam air ketuban pada kasus persalinan preterm spontan dengan selaput ketuban yang masih intak. (Med J Indones 2001; 10: 203-9)
\end{abstract}

\begin{abstract}
Pre-term labor is presumed to result from spreading of lower genital infection to upper part, subsequently to decidual and chorioamniotic tissues. Host response to this injury include the expression of protein which is responsible to the inflammatory reactions. The expression of the inflammatory cytokines such as $I L-1 \beta, I L-6, I L-8$ and $T N F-\alpha$ increase in case of infection. These cytokines may play an essential role in the pathophysiology of spontaneous preterm labor with intact membrane. An observational analytic cohort study was carried out on cases of spontaneous pre-term labor with intact membrane. The objectives of this study are to examine the relationship between 1) the histologic amnionitis and placentitis and the incidence of preterm delivery,2) the expression of amniotic fluid's $I L-1 \beta, I L-6, I L-8, T N F-\alpha$ and the incidence of preterm delivery, 3) the level of amniotic fluid's $I L-1 \beta$, $I L-6, I L-8, T N F-\alpha$ and the grade of histologic amnionitis and placentitis in case of pre-term labor with intact membrane. Cases of spontaneous pre-term labor with intact membrane which underwent transabdominal amniocentesis at admission and managed as standard procedure for pre-term labor with intact membrane. All of the cases were observed until the delivery of the baby, either preterm or term. The membrane and the placenta were cut postnatally and then the histologic acute inflammation evaluated based on the criteria of Salafia.The level of amniotic fluid $I L-1 \beta, I L-6, I L-8$ and TNf- $\alpha$ were analyzed quantitatively by Elisa method. This study showed that the degree of histologic amnionitis and placentitis, and the level of amniotic fluid's IL-1 $\beta, I L-6, I L-8$ and TNF- $\alpha$ were significantly higher in pre-term compared to term deliveries $(p<0.05)$ and there were a positive correlation between the grade of histologic inflammation and the level of amniotic fluid's cytokines (Spearmann Rank Correlation test; $p<0,05$ ) in cases of preterm labor with intact membrane. The higher the grade of histologic amnionitis and placentitis, the higher the level of amniotic fluid's IL-1 $\beta$, $I L-6, I L-8$ and TNF- $\alpha$ resulting in a higher risk of pre-term delivery in case of preterm labor with intact membrane. These correlation may

Division of Fetomaternal Medicine, Department of Obstetrics and Gynecology, Medical Faculty of Airlangga indicate a progression of inflammation from placenta and membrane into the amniotic cavity. (Med J Indones 2001; 10: 203-9)
\end{abstract} University, Surabaya, Indonesia
Keywords: Inflammation, Preterm Labour 
The incidence of preterm delivery varies from country to country and remain unchanged during the last two to three decades. ${ }^{1}$ In developed countries, the incidence of preterm delivery probably lies between 5 to $10 \%$ of all births. In Dr. Soetomo General Hospital of Surabaya, the incidence of preterm delivery is about $19.4 \%{ }^{2}$ In Indonesia, preterm delivery accounts for about 70 to $80 \%$ of total perinatal death without congenital malformation. Mortality rates for premature infant in the first year of live range from 40 to $70 \%$. Further more, there are still high incidence of short term complications of premature infants because of biologically immature organs such as respiratory distress, intraventricular haemorraghe and necrotizing enterocolitis. The long term handicap caused by prolonged fetal hypoxia (hypoxic ischemic encephalopathy) with varied clinical manifestations such as cerebral palsy, blindness, deafness and mentally retardation are still a problem of health expences in developing countries, however, these type of care are considered low priority. ${ }^{3,4}$ The aetiology of preterm labor is poorly understood but certain associated factors are known. In the past decade there had been mounting evidence of a link between genital infection and preterm labor. The previous study found about 70 to $80 \%$ preterm labor had a positif correlation with vagino-cervical infection., ${ }^{5,6}$ Joesoef et al, in bacterial vaginosis study on preterm deliveries in Indonesia found higher incidence of preterm deliveries in the earlier gestational age $(20,5 \%)$, as compared to women who had bacterial vaginosis in late pregnancy $(10,7 \%){ }^{7}$ There were many clinical evidence explained the role of inflammation in the patophysiology of preterm labor. Preterm labor is presumed to result from the spreading of infection of tract lower genital to the upper part, subsequently involving the decidual and chorioamniotic tissue. ${ }^{8.9}$ The expression of inflammatory cytokines increases in case of infection. ${ }^{10}$ These cytokines may play an essential role in the patophysiology of preterm labor with intact membrane. These cytokines might activate the biochemical cascade of prostaglandines biosyntesis (PGE-2 and PGF-2 $\alpha$ ), which lead to myometrial contraction, cervical changes and initiating the labor. ${ }^{11}$

\section{Chorioamnionitis and intraamniotic infection}

Generally, chorioamnionitis is defined as an inflammatory reaction of the chorioamniotic tissue as a response to injury caused by trauma, infection, chemicals and neoplasma. In case of infection, most of the vaginal microbes produce mucinase and sialidase, enzymes that may alter the immune system in the cervical mucous. In this condition, the microorganisms may gain access to cervical canal, membrane, placenta and intraamniotic cavity. Moreover, these microorganisms directly or indirectly stimulate collagenase and elastase activity. The activation of macrophages and other cells, will express the inflammatory mediators or cytokines such as $\Pi-1 \beta, \pi-6, \Pi-8$ and TNF- $\alpha . .^{2,13}$ Chorioamnionitis and intraamniotic infection are presumed to result from the invasion of abnormal growth of cervicovaginal facultative microorganisms to upper genital tract, and subsequently the gestational tissues (decidua, chorion and amnion), intraamniotic cavity. Another pathway, the microorganims may gain access to the fetus through the cord blood circulation (funiculitis, choriovasculitis). ${ }^{14}$

The objectives of this study are to prove :

1. the relationship between the evidence of histologic amnionitis and placentitis and the incidence of preterm labor with intact membrane.

2. the relationship between the expression of amniotic fluid's IL- $1 \beta, \mathbb{L}-6, \Pi \mathrm{L}-8, \mathrm{TNF}-\alpha$ and the incidence of preterm labor with intact membrane.

3. the correlation between the level of amniotic fluid's $\Pi-1 \beta$, IL- $6, \pi-8$, TNF- $\alpha$ and the grade of histologic amnionitis and placentitis in case of preterm labor with intact membrane.

\section{METHODS}

The design of this study was an observational analytic cohort study with internal control, conducted in cases of spontaneous preterm labor with intact membrane presumed caused by infection. ${ }^{15}$

The study was performed in the delivery room of the Emergency Care Instalation of Dr. Soetomo General Hospital, Surabaya, Indonesia.

The inclusion criteria were gestational age of 28 to 34 weeks, intact membrane and the sign in labor (contraction of $\geq 2$ per 10 minutes and effacement of $\geq 50 \%$ or dilatation of $\leq 3 \mathrm{~cm}$ ). And the exclusion criteria were hypertension, diabetes mellitus, twin pregnancy, polyhydramnios, antepartum haemorrhage, 
uterine anomaly, fetal anomaly and gynecologic tumor. Transabdominal amniocentesis was performed at admission and managed as standard procedure for preterm labor with intact membrane. All of these cases were observed untill the delivery of the baby, either preterm or term. The membrane was cut 2 to 3 centimeters arround the tear and the placenta was cut the whole thickness 3 to $5 \mathrm{~cm}$ arround the cord and then the histologic inflammation of the membranes and placentas were evaluated based on the criteria of Salafia.

Twenty mililiters of the amniotic fluid was centrifuged at $1500 \mathrm{rpm}$ for 10 minutes, the supernatant was collected and incubated in $-80^{\circ}$ Celcius. The level of $\mathbb{I}-1 \beta$, IL-6, IL-8 and TNf- $\alpha$ were analyzed quantitatively by Elisa method (Millenia, End Point Enzyme Immunometric Assay, GmBH Biermann) simultantly (50 cases).

The standard procedure of management on pre-term labor with intact membrane were hospitalization and bed rest, parenteral betamethasone $16 \mathrm{mg}$ /day intramuscularly for two consecutive days to promote fetal lung maturation, parenteral ampicillin sulbactam $1,5 \mathrm{~g} /$ day intravenously for two days, proceeded by $750 \mathrm{mg} /$ day orally in two divided doses for 5 days. Tocolytic agent was given, starting with $1000 \mathrm{mcg}$ of parenteral Terbutaline in $500 \mathrm{ml} \mathrm{NaCL} 0.9 \%$. The initial dose was was $1 \mathrm{mcg} /$ minute or $10 \mathrm{drops} /$ minute, increased by $0.5 \mathrm{mcg} /$ minute or 5 drops/minute in every 15 minutes until the contraction disappeared or serious maternal or fetal side effect developed. Maximum dose was $5 \mathrm{mcg} /$ minute (50 drops per minute). As the contraction disappeared, the therapeutic level should be maintained until one hour and then decrease the dose 5 drops every 15 minutes. The maintenance dose was 10-20 drops/minute for 8 hours. If the contraction reappeared during maintenance, the dose should be increased and the previous procedures repeated. It is recommended that $2000 \mathrm{mcg} / 1000 \mathrm{ml} \mathrm{NaCL} 0.9 \%$ as total dose may be given. Oral terbutaline of $7.5 \mathrm{mg} /$ day in three divided doses was given for 5 days and started 30 minutes before parenteral terbutaline were stopped. During the tocolytic treatment, the maternal side effect (tachycardia and pulmonary oedema) and sign of fetal hypoxia should be monitored continuously. As the sign of side effect appear, the tocolytic treatment should be stopped instantly and the patient supported against complications.
The exposures (independent variables) are the grade of histologic inflammation of membrane and placenta based on the criteria of Salafia and the level of amniotic fluid $\mathbb{L}-1 \beta, \mathbb{L}-6, \mathbb{L}-8$ and TNf- $\alpha$, analyzed quantitatively by Elisa.

The outcomes (dependent variables) are preterm deliveries with gestational age of $<37$ weeks, according to the last period and Dubowitz score at birth and term deliveries with gestational age of 37 weeks or more, according to the last period at birth.

Salafia's grading system for histologic inflammation of the membrane and placenta. ${ }^{16}$

Inflammation of the membrane.

Grade 1 : One focus of at least 5 neutrophyls.

Grade 2 : More than one focus of grade 1, or at least one focus of 5-20 neutrophils.

Grade 3 : Multiple or confluents foci of grade 2.

Grade 4 : Diffuse and dense acute inflammation.

Inflammation of the placenta.

Grade 1 : One focus of at least 5 neutrophils in subchorionic fibrine.

Grade 2 : Multiple foci of grade 1 in subchorionic fibrine.

Grade 3: Few neutrophils in connective tissue or chorionic plate.

Grade 4: Numerous neutrophils in chorionic plate and sign of acute inflammation of chorionic vessels ( chorionic vasculitis)

The chi square test or student t-test were carried out to evaluate the homogeneity between groups. Risk analysis study was done to know the risk of specific exposures and Spearmann Rank Correlation test was carried out for correlation among exposures (inflammation and cytokines expression).

\section{RESULTS}

Fifty cases of spontaneous preterm labor with intact membrane, who fulfilled the inclusion and exclusion criterias were included in this study.

At the end of this study there were 30 pre-term delivery cases (60\%) with the gestational age of 32.2 \pm 1.7 weeks, birth weight of $1635.0 \pm 356.3$ grams and delivered at $5.8 \pm 5.2$ days after amniocentesis, and 20 term delivery cases $(40 \%)$ with the gestational 
age of $37.7 \pm 1.3$ weeks, birth weight of $2772.5 \pm$ 277.4 grams and delivered at $40.4 \pm 15.4$ days after amniocentesis. The distribution of cases according to maternal age, parity, education and occupation between groups (preterm and aterm) were not significantly different, but there was a difference on the gestational age at admission $(\mathbf{p}<0,05)$. The earlier the gestational age at admission the higher the incidence of preterm delivery in case of spontaneous labor with intact membrane.

The role of histologic amnionitis and placentitis on the incidence of preterm delivery in case of preterm labor with intact membrane.

The histology of acute inflammation of membrane and placenta were divided into 4 grades of Salafia's criteria. To evaluate the role of these exposures and to make easier the statistical analysis, it were categorized into :

First Category :

- Positive : if there was a sign of Salafia's inflammation.

Negative : if there was no sign of Salafia's inflammation.

Second Categories :

- Severe : if there was a sign of Salafia's inflammation grade 2 to 4 .

- Mild : if there was a sign of Salafia's inflammation grade 1 .

Negative : if there was no sign of Salafia's inflammation.

Based on the first category (table 1), there was a significant difference in the outcome of delivery (preterm and term). There were $81.3 \%$ and $76.9 \%$ of preterm delivery with a sign of inflammation, as compared to only $22.2 \%$ and $41.7 \%$ with no sign of inflammation of membrane and placenta (df. $1 ; \mathrm{p}<0,01$ ). Moreover, it was found that the inflammation of the membrane lead to a higher risk of preterm delivery than the inflammation of the placenta (RR. 3,66 versus $1,85)$.

Based on the $2^{\text {nd }}$ category (table 2), there was $91.35 \%$ and $100 \%$ cases of preterm deliveries with severe inflammation of membrane and placenta respectively while only $55.6 \%$ and $22.2 \%$ with mild and no inflammation of the membrane and $64.7 \%$ and $41.7 \%$ with mild and no inflammation of the placenta (df.2; $\mathrm{p}<0,01)$. It showed clearly the role of the grade of histologic inflammation in the incidence of preterm delivery in case of preterm labor with intact membrane.

According to this phenomena, the higher the grade of inflammation, the higher the risk of preterm delivery (RR.4.11 vs 2.50 for the inflammation of the membrane and RR.2.40 vs 1.55 for the inflammation of the placenta). Single table analysis of cases with mild and no inflammation showed no significant risk on the incidence of preterm delivery. So we conclude that only cases with severe inflammation lead to significant risk of preterm delivery in case of preterm labor with intact membrane $(\mathrm{p}<0.05)$.

Table 1. The outcome of the delivery by the $1^{\text {st }}$ category of inflammation

\begin{tabular}{|c|c|c|c|c|}
\hline Inflammation & $\begin{array}{c}\text { Preterm } \\
\quad(30)\end{array}$ & $\begin{array}{r}\text { Term } \\
(20)\end{array}$ & $\mathrm{N}$ & RR Chi Sq \\
\hline Membrane (+) & $26(81.3 \%)$ & $6(18.7 \%)$ & 32 & 3,66 df. 1 \\
\hline Membrane (-) & $4(22.2 \%)$ & $14(77.8 \%)$ & 18 & $\mathrm{p}<0,01$ \\
\hline Placenta (t) & $20(76.9 \%)$ & $6(23.1 \%)$ & 26 & 1,85 \\
\hline Placenta $(-)$ & $10(41.7 \%)$ & $14(58.3 \%)$ & 24 & $p<0,01$ \\
\hline
\end{tabular}

Table 2. The outcome of the delivery based on the second category.

\begin{tabular}{cccccc}
\hline Inflammation & $\begin{array}{c}\text { Preterm } \\
(30)\end{array}$ & Term & N & RR & Chi Sq.
\end{tabular}

\begin{tabular}{lcrrrc}
\hline Membrane : & & & & & \\
a severe & $21(91.35 \%)$ & $2(8.70 \%)$ & 23 & 4.11 & df. 2 \\
mild & $5(55.6 \%)$ & $4(44.4 \%)$ & 9 & 2.50 & $\mathrm{p}<0.01$ \\
negative & $4(22.2 \%)$ & $14(77.8 \%)$ & 18 & & \\
Placenta : & & & & & \\
a severe & $9(100 \%)$ & $0(0.00 \%)$ & 9 & 2.40 & df. 2 \\
mild & $11(64.7 \%)$ & $6(35.3 \%)$ & 17 & 1.55 & $\mathrm{p}<0.01$ \\
negative & $10(41.7 \%)$ & $14(58.3 \%)$ & 24 & & \\
\hline
\end{tabular}

The increase of the expression of amniotic fluid's $I L$ $1 \beta, I L-6, I L-8$ and TNF- $\alpha$ in case of spontaneous preterm labor with intact membrane.

The basic understanding of the mechanism of preterm labor caused by infection was the host response 
against injury. The expression of inflammatory cytokines may play an essential role.

Table 3. The level of amniotic fluid's IL-1 $\beta$, IL-6, IL- 8 and TNF- $\alpha$ in preterm and term delivery in case of preterm labor with intact membrane.

\begin{tabular}{lccccc}
\hline Cytokines & $\begin{array}{c}\text { Preterm } \\
(30)\end{array}$ & $\begin{array}{c}\text { Term } \\
(20)\end{array}$ & $\mathrm{t}$ & $\mathrm{df}$ & $\mathrm{P}$ \\
\hline IL-1 $\beta$ & $253.3 \pm 379.5$ & $2.55 \pm 5.97$ & 3.62 & 29.02 & $<0.01$ \\
IL-6 & $11966.0 \pm 8471.0$ & $1045.6 \pm 965.3$ & 6.99 & 30.12 & $<0.01$ \\
IL-8 & $3577.7 \pm 2472.8$ & $1223.0 \pm 799.5$ & 4.85 & 37.40 & $<0.01$ \\
TNF- $\alpha$ & $56.6 \pm 115.0$ & $00.0 \pm 00.0$ & 2.70 & 29.00 & 0.01 \\
\hline
\end{tabular}

Table 3 showed that the level of amniotic fluid's IL$1 \beta, \mathrm{IL}-6, \mathbb{L}-8$ and TNF- $\alpha$ were significantly higher in preterm than term deliveries $(\mathrm{p}<0.05)$. The increase of these levels, might suggest the important role of those cytokines on the patophysiology of preterm labor caused by infection.

The correlation between the level of amniotic fluid's IL$I \beta, I L-6, I L-8$ and $T N F-\alpha$ and the grade of histologic inflammation of the membrane and placenta in case of preterm labor with intact membrane.

The evidences above (table 2 and 3), showed that, the higher grade of histologic inflammation of the membrane and placenta, and level of $\Pi-1 \beta, \Pi-6$, IL-8 and TNF- $\alpha$ were found in preterm delivery as compared with term delivery. It might give an impression that there was a basic reason of the initiation of spontaneous preterm labor with intact membrane. Furthermore, we had to appraise the correlation between the grade of histologic inflammation and the increase of the level of amniotic fluid's cytokines.

Spearmann Rank Correlation analysis was carried out to see whether any correlation between the increase of the grade of histologic inflammation and the level of amniotic fluid's $\Pi \mathrm{L}-1 \beta, \Pi \mathrm{L}-6, \Pi \mathrm{L}-8$ and TNF- $\alpha$ in case of preterm labor with intact membrane. It was found that there was a positive corellation between the grade of inflammation and the level of amniotic fluid's cytokines $(\mathrm{p}<0.05)$ (table 4$)$. It could be concluded that the higher the grade of histologic inflammation of membrane and placenta, the higher the level of amniotic fluid's IL-1 $\beta, \Pi L-6, \mathrm{IL}-8$ and TNF- $\alpha$, in cases of preterm labor with intact membrane.
Table 4. Spearmann Rank Correlation analysis on the grade of histologic amnionitis and placentitis and the level of amniotic fluid's IL-1 $\beta$, IL-6, IL- 8 and TNF- $\alpha$ in cases of preterm labor with intact membrane.

\begin{tabular}{lccccc}
\hline Cytokines & $\mathrm{N}$ & \multicolumn{2}{c}{ Amnionitis } & \multicolumn{2}{c}{ Placentitis } \\
& & $\mathrm{r}$ & $\mathrm{p}$ & $\mathrm{r}$ & $\mathrm{p}$ \\
\hline IL-1 $\beta$ & 50 & 0.3751 & 0.01 & 0.4740 & 0.01 \\
IL-6 & 50 & 0.5968 & 0.01 & 0.4340 & 0.01 \\
IL-8 & 50 & 0.5731 & 0.01 & 0.5136 & 0.01 \\
TNF- $\alpha$ & 50 & 0.3828 & 0.01 & 0.4307 & 0.01 \\
\hline
\end{tabular}

\section{DISCUSSION}

Preterm labor may be due to a normal signal occuring too early in pregnancy, but it is more likely to be due to an abnormal signal, and there is increasing evidence that infection may be such a trigger. ${ }^{17,18}$ Since the last two decades the incidence of preterm delivery did not reduce significantly. The decline in perinatal morbidity and mortality is largely attributable to improved neonatal intensive care, which has been achieved at great expense. However, to prevent preterm delivery before the clinical sign of labor extend may reduce the cost of neonatal care and decrease the perinatal morbidity and mortality. ${ }^{3}$

Most investigators found an increasing evidence that genital infection in the mother may be responsible for a proportion of spontaneous preterm labor and premature rupture of the membrane. These evidence is based on the organisms found in vagina, cervix and amniotic fluid of women in preterm labor, the evidence of chorioamnionitis among women with preterm birth and the reduction of prematurity among pregnant women treated with antibiotics. ${ }^{19}$

Preterm labor is presumed to result from migration of lower genital infection to upper part, subsequently to decidual and chorioamniotic tissues. Host response to this injury include the expression of proteins which are responsible for the inflammatory reactions. Decidual and chorioamniotic cells express the basal cytokines. $^{20,21}$ The expression of the inflammatory cytokines such as IL-1 $1 \beta$, IL- 6 , IL- 8 and TNF- $\alpha$ increased in case of infection. ${ }^{1,9,10,22}$ In previous cross sectional studies there were more evidences of a link between histologic chorioamnionitis and the incidence of preterm labor (table 5), however, those studies did 
not prove the causal relationship between infection and preterm labor.

Table 5. Several investigators' report on the incidence of chorioamnionitis in preterm and term deliveries.

\begin{tabular}{|c|c|c|c|}
\hline \multirow[t]{2}{*}{ Investigator } & \multirow[t]{2}{*}{ Year } & \multicolumn{2}{|c|}{ Chorioamnionitis } \\
\hline & & Preterm & Term \\
\hline Hillier, et $\mathrm{al}^{5}$ & 1991 & - & $21 \%$ \\
\hline Cherouny $^{23}$ & 1992 & $82 \%$ & - \\
\hline Greig, et al ${ }^{16}$ & 1993 & $88 \%$ & $23 \%$ \\
\hline Yoon, et $\mathrm{al}^{24}$ & 1995 & $66 \%$ & - \\
\hline Abadi, et al ${ }^{19}$ & 1998 & $71,4 \%$ & $39,3 \%$ \\
\hline
\end{tabular}

This present study had shown that in cases of preterm labor with intact membrane, the grade of histologic amnionitis and placentitis and the level of $\mathrm{IL}-1 \beta$, $\Pi-6$, IL- 8 and TNF- $\alpha$ were significantly increased. Based on the $1^{\text {st }}$ category of inflammation (presence and absence of inflammation) it had been proven that there were significant differences between the incidence of preterm delivery with and without inflammation of the membrane ( $81.3 \%$ vs $22.2 \%$ ) and placenta $(76.9 \%$ vs $41.7 \%)$. Looking at the $2^{\text {nd }}$ category of inflammation (severity, mildness and absence of inflammation), it showed that only cases with severe inflammation (grade 2 - 4 of Salafia's) lead to the significant risk for preterm delivery $(p<0.05)$. The mild (grade 1 of Salafia's) and those without inflammation had no significant risk for preterm delivery $(p>0.05)$. It can be concluded that the higher the grade of histologic inflammation, the higher the possibility for preterm delivery. As we know, the design of this study was prospective cohort, most likely to prove the causal relationship between those inflammation and preterm delivery. ${ }^{15}$

In this study we found that the level of amniotic fluid's $\Pi L-1 \beta, \Pi L-6, \pi-8$ and TNF- $\alpha$ significantly increased in preterm deliveries as compared to those in term. This result showed that the inflammatory response was stronger in preterm than term delivery. To assess the relationship between the grade of histologic inflammation and the increase of the level of the inflammatory cytokines, Spearmann Rank Corellation analysis was carried out. This analysis showed significantly positive corelation (table 4). It means that the higher the grade of hystologic inflammation of membrane and placenta, the higher the level of amniotic fluid's inflammatory cytokines.
So, the level of the amniotic fluid's IL-1 $\beta$, IL-6, IL-8 and TNF- $\alpha$ might indicate the grade of histologic amnionitis and placentitis. It is the same as the previous study where there was a significant positive corellation between the grade of histologic chorioamnionitis and the level of Interleukin-6 in preterm delivery. ${ }^{16,24}$

\section{CONCLUSION}

In such patients with spontaneous preterm labor and intact membrane, there are evidence that the grade of histologic amnionitis and placentitis are significantly higher in preterm than term delivery. The levels of amniotic fluid's $\mathbb{L}-1 \beta, \Pi-6, \Pi-8$ and TNF- $\alpha$ are markedly increased in preterm compared to term deliveries and there is significant positive corellation between the grade of histologic inflammation and the levels of amniotic fluid's inflammmatory cytokines. These correlations may indicate a progression of inflammation from placenta and membrane into the amniotic cavity. Assuming that most inflammatory lesions of the membrane and placenta were due to infection, it strongly suggest that infection of gestational tissue may be responsible for the incidence of preterm labor and delivery.

\section{REFERENCES}

1. Lamont RF. The role of infection in the pathogenesis of preterm labor. In: Progress on Obstetrics and Gynecology. Vol 10. Churchill \& Livingstone; 1995. p. 135-58.

2. Abadi A, Sulistiono A. The difference of histologic membranitis and placentitis between preterm and term deliveries. Maj Obstet Ginekol 1998; 7: 30-5.

3. Mc Gregor JA, French JL. Preterm Birth. The role of infection and inflammation. Medscape Women Health 2(8). Medscape Inc. 1997.

4. Wiknjosastro G. Antenatal Infection and Preterm Labor. J Ped Obstet Gynecol 1998; 24:27-30.

5. Hillier SL, Krohn MA, Kiviat MB, Watts DH, Eschenbach DA. Microbiologic causes and neonatal outcomes. Associated with chorioamniotic infection. Amer J Obstet Gynecol. 1991; 165: 955-61.

6. Gibbs RK, Romero R, Hillier SL, Eschenbach DA, Sweet RL. A review of premature birth and subclinical infection. Amer J Obstet Gynecol. 1992; 166:1515-28.

7. Joesoef MR, Hillier SL, Utomo B, Wiknyosastro G, Linnan NM, Kandun M. Bacterial Vaginosis and Prematurity in Indonesia. Associated in Early and Late Pregnancy. Amer J Obstet Gynecol. 1993; 169: 175-8. 
8. Lockwood CJ. The Diagnosis of preterm labor and the prediction of preterm delivery. Clin Obstet Gynecol 1995; 38: 675-87.

9. Kellan JA, Coleman M, Mitchell MD. The Molecular mechanism of term and preterm labor. Recent progress and clinical implcation. J Clin Endocr Metab 1996; 81: 2579-86.

10. Kunkel SL, Lukacs N, Strieter RM. Cytokines and inflammatory disease. A cause and cure. J. Clin Immunol $1992 ; 12: 61$

11. Cunningham FG, Mac Donald PC, Gant NF, Leveno KJ. Parturition. Preterm labor. In: William's Obstetrics. $20^{\text {th }}$ Ed. Chapter 11. London, Appleton \& Lange. 1997; p. 306-13.

12. Beckerman LP. Reproduction and the immune system. Basic and clinical immunology. Stites et al (eds). $8^{\text {th }}$ Ed. Section III. London, Appleton \& Lange 1994. p.552-67.

13. Pimentel E. Tumor Necrosis Factors. In: Handbook of growth factors. Vol. III. Hematopoietic growth factors and cytokines. Chap. 5. 1994. p. 241-61.

14. Romero R, Yoon BH, Mazor M, Gomez R, Diamond M, Kenney J. The Diagnostic and prognostic value of amniotic fluid white blood cells count, Glucose, Interleukin-6 and Gram stain in patients with preterm labor and intact membranes. Amer J Obstet Gynecol 1993; 169:805-16.

15. Gordis L. More on risk. Estimating the potential for prevention. In: Epidemiology. Chapter 10. Phyladelphia. WB Saunders Co. 1997. p. 155-62.

16. Greig PC, Emest JM, Teot L, Erickson I, Talley R. Amniotic fluid interleukin-6 level corellated with histologic chorioamnionitis and amniotic fluid cultures in patients of premature labor with intact membrane. Amer J Obstet Gynecol 1993; 169: 1035-44.

17. Mitchell DM, Trautman MS, Dudley DJ. Immunoendocrinology of preterm labor and delivery. Balliere's Clinical Obstetric \& Gynecology 1993; 7: 553-75.

18. Herman AA, Carrey JC. The role of infection in precipitating preterm labor. Obstetric \& Gynecologic Infectious disease. Pastorek (ed) II. New York Raven Press. 1994. p. 267-74.

19. Abadi A. The inflammation of the membrane, placenta and amniotic fluid's interleukin- 6 as determinant factor for preterm delivery in case of preterm labor with intact membrane. Disertation; 1999.

20. Hamblin AS. Cytokines and cytokine receptors. Oxford University Press. Inc New York. 1993; p. 21-40.

21. Maradny E, Kanayama N, Abdul Halim, Maehara K, Sumimoto K. Interleukin-8 induce cervical ripening in rabbit. Amer J Obstet Gynecol 1994; 171: 77-83.

22. Bernal AL, Watson SP, Phaneuf $S$, Finner GN. Biochemistry and physiology of preterm labor and delivery. Balliere's Clinical Obstetric \& Gynecology. 1993; 7:523-52.

23. Cherouny P, Pankuch G, Applebaum P. The presence of amniotic fluid leucoattractant accurately identifies histologic chorioamnionitis and predict tocolytic efficacy in patients with idiophathic preterm labor associated with infection. Amer J Obstet Gynecol 1992; 167:683-8.

24. Yoon BH, Romero R, Kim CJ, Jun JK, Gomez R, Choi JH, Syn HC. Amniotic Fluid Interleukin-6. A Sensitive Test for Antenatal Diagnosis of Acute Inflammatory Lesion of Preterm Placenta and Prediction of Prenatal Morbidity. Amer J Obstet Gynecol 1995; 172:960-70. 